\title{
Egg laying performance and economics of production of japanese quails fed diets containing peeled and cooked sweet potato meal
}

${ }^{1}$ Edache, J. A., ${ }^{2}$ Tuleun, C. D., ${ }^{2}$ Oluremi, O. I. A. and ${ }^{2}$ Carew, S. N.

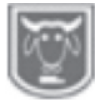

${ }^{\prime}$ Federal College of Animal Health and Production Technology, Vom,

${ }^{2}$ University of Agriculture, Makurdi.

Abstract

Correspondence: (amedzion@yahoo.com) 08037024295

Japanese quails are small in size, early maturing, come to egg production between $5^{\text {th }}$ and $6^{\text {th }}$ week of life, hardy and prolific but requires local feeds for sustainability. Thus, a feeding trial which lasted for six months was carried out to investigate the effect of feeding peeled and cooked sweet potato tuber on hen-day egg production and economics of production of Japanese quails. Five isonitrogenous $(20 \% \mathrm{CP})$ diets were compounded. The control diet (A) had zero sweet potato tuber meal. In the other four diets, 25, 50, 75 and 100\% of maize was replaced with peeled and cooked sweet potato tuber meal. Three hundred point-of-lay female Japanese quail birds were randomly allotted to the diets in a completely randomized design. Feed and water were provided ad libitum for six months. Each diet was allocated to 60 quail chicks, which were further divided into three replicates of 20 birds each to determine the performance characteristics of the quails. Feed intake, body weight change, age at first eggs, age at $50 \%$ egg production, age at $75 \%$ egg production, hen-day egg production, hen-housed egg production and feed per dozen eggs were similar ( $p f$ i 0.05) across the diets. Water intake by birds on diet A was significantly (pfi 0.05) lower than the birds on the sweet potato diets. Water intake was significantly ( $p f$ 0.05) higher by birds on diet D (51.93ml/bird/day) than those on diets $A(42.60)$ and $C(46.68 \mathrm{~mL} / \mathrm{bird} /$ day). Total cost of production did not differ significantly across the diets. Gross margin was significantly higher on diet $C$ (N67, 227.64) than on the other diets except for diet D (N65, 795.52). Results showed that peeled and cooked sweet potato can completely replace maize in the diet of laying quails without adverse effects on performance or on economics of production.

Keywords: Feed intake, water intake, hen-day egg production, hen-housed egg production, economics of production.

\section{Introduction}

There are about 50 genera and more than 1000 species of sweet potato with the family name called convulvulaceae. Sweet potato (Ipomoea batatas), a member of this family, is the only crop plant whose large starchy, tasty tuberous root is an important root vegetable (Purseglove, 1991). It is widely cultivated in the tropics and the warmer temperate climates. The edible part is an enlarged tuberous root, varying from oblong to pointed ovalin shape. Neild (1992) reported that the solid root consists largely of starch and that the orange- fleshed varieties are high in carotene, vitamin A and
$\mathrm{B}_{6}$ or pyridoxine. Studies by Oboh (1987) and Tewe (1992) have shown that sweet potato is utilized efficiently by poultry. Ladokun et al. (2007) reported that not more than $50 \%$ of maize should be replaced by sweet potato meal in the diet of laying chickens to maintain profitable performance. However, Aina and Fanimo (1997) reported that hen-day egg production, egg weight, feed intake and shell thickness did not differ significantly between birds fed maize-based diets and those fed sweet potato diets. Maphosa et al. (2003) and Afolayan et al. (2012) reported that addition of sweet potato to broiler diet 
negatively affected their performance and that not more than $50 \%$ of maize should be replaced with sweet potato meal in finisher diet to avoid adverse effect on performance. Japanese quail are small-sized, come to egg production between the $5^{\text {th }}$ and $6^{\text {th }}$ week of life (Martins, 1987), are early maturing, hardy and prolific (Robbins, 1981). The eggs are small, multicolored and weigh between 8 and $10 \mathrm{~g}$ each (Edache et al., 2003a; Musa et al., 2008). The meat and eggs are low in body fat and cholesterol which is of public health significance. Increased production of this bird with adequate nutrition will ensure constant availability to teaming consumers. Eighteen to twenty percent crude protein diet has been recommended for acceptable egg laying for Japanese quail (Edache et al., 2003b).

The objective of this study was to determine the effect of replacing maize with peeled cooked sundried sweet potato tuber meal on hen-day egg production and economics of productionof Japanese quails.

\section{Materials and methods \\ Source and processing method of sweet potato tuber}

The white-fleshed sweet potato tuber used in this study was purchased from Jos and from a border market between Plateau and Kaduna States. The sweet potato tubers were cleaned for processing. The sweet potato tubers were peeled, sliced $(3 \mathrm{~mm})$, cooked (20 minutes) and sun-dried for seven days. The cooking was done by pouring the sliced sweet potato tubers into boiling water and left to boil for 20 minutes. A hammer mill fitted with an $8 \mathrm{~mm}$ sieve was used to mill the processed sweet potato tubers and thereafter incorporated into experimental diets. The diets were analyzed for proximate chemical components as outlined (AOAC, 2000).

\section{Experimental birds}

Three hundred point-of-lay Japanese quails purchased from Poultry Division, National Veterinary Research Institute, Vom were used in the study. They were healthy and uniform in body weight and size (of average of $155 \mathrm{~g}$ per bird).

\section{Experimental design and housing}

The three hundred point-of-lay quails were randomly allotted to five dietary treatments in a completely randomized design. Each treatment group had 60 quails and was replicated thrice. Each replicate had twenty quails which were housed in a standard deep litter poultry house spaced $150 \mathrm{sq} \mathrm{cm}$ per bird as recommended by Musa et al. (2008).

\section{Experimental diets}

Peeled cooked sundried sweet potato meal was used to replace maize in five isonitrogenous $(20 \% \mathrm{CP})$ diets. Diet A without peeled and cooked sweet potato served as the control. In diets B, C, D and E, $25 \%, 50 \%, 75 \%$ and $100 \%$ of maize in the diets was replaced by peeled and cooked sweet potato meal, respectively. The diets were fortified with vitamins and minerals. The ingredient and nutrient composition of the experimental diets are presented in Tables 1 and 2, respectively.

\section{Management of birds and data collection}

Each treatment group of birds was fed one of the five experimental diets in which 0 , $25,50,75$ and $100 \%$ of maize was replaced by peeled and cooked sweet potato meal, respectively. The birds were fed the experimental diets daily and corresponding leftover weighed to determine feed intake. Water intake was measured daily using a calibrated cylinder. All birds were given feed and water ad libitum throughout the experimental. All birds in each replicate were weighed at the start of the feeding trial and once a week for the period of the feeding trial. Daily egg collection was carried and sample of eggs from each 
Table 1: Percent ingredient composition of experimental diets for laying quails

\begin{tabular}{|c|c|c|c|c|c|}
\hline \multicolumn{6}{|c|}{ Diets } \\
\hline Ingredients & $\mathrm{A}$ & $\mathrm{B}$ & $\mathrm{C}$ & $\mathrm{D}$ & $\mathrm{E}$ \\
\hline Maize & 40.23 & 29.26 & 18.27 & 7.25 & 0 \\
\hline Sweet potato meal & 0 & 10.06 & 20.11 & 30.22 & 40.23 \\
\hline Ground nut cake & 25.57 & 26.48 & 27.41 & 28.33 & 30.31 \\
\hline Wheat offal & 10.00 & 10.00 & 10.00 & 10.00 & 10.00 \\
\hline Fish meal & 1.00 & 1.00 & 1.00 & 1.00 & 1.00 \\
\hline Palm kernel cake & 14.00 & 14.00 & 14.00 & 14.00 & 14.00 \\
\hline Bone meal & 2.00 & 2.00 & 2.00 & 2.00 & 2.00 \\
\hline Limestone & 6.50 & 6.50 & 6.50 & 6.50 & 6.50 \\
\hline *Vit. Premix & 0.25 & 0.25 & 0.25 & 0.25 & 0.25 \\
\hline Salt & 0.25 & 0.25 & 0.25 & 0.25 & 0.25 \\
\hline Lysine & 0.10 & 0.10 & 0.10 & 0.10 & 0.10 \\
\hline Methionine & 0.10 & 0.10 & 0.10 & 0.10 & 0.10 \\
\hline Total & 100 & 100 & 100 & 100 & 100 \\
\hline \multicolumn{6}{|c|}{ Calculated composition: } \\
\hline C.P. $\%$ & 20.00 & 20.00 & 20.00 & 20.00 & 20.00 \\
\hline \multicolumn{6}{|l|}{ M.E. } \\
\hline (Kcal/kg) & 2575.83 & 2521.79 & 2467.57 & 2413.24 & 2377.48 \\
\hline Ca. $(\%)$ & 3.17 & 3.18 & 3.18 & 3.18 & 3.19 \\
\hline $\mathrm{P}(\%)$ & 0.47 & 0.47 & 0.47 & 0.46 & 0.45 \\
\hline C.F. $(\%)$ & 4.63 & 5.05 & 5.48 & 6.90 & 6.17 \\
\hline Cost/kg Diet ( $)$ & 63.72 & 62.99 & 62.26 & 61.53 & 61.04 \\
\hline
\end{tabular}

Table 2: Nutrient composition (\%) of laying quail diets used in the experiment

\begin{tabular}{lllllll}
\hline Parameters (\%) & A & B & C & D & E & SEM \\
\hline Dry matter & 94.70 & 94.50 & 94.39 & 94.04 & 94.22 & $\pm 0.43 \mathrm{NS}$ \\
Crude Protein & 20.10 & 20.10 & 20.08 & 20.11 & 20.10 & $\pm 0.06 \mathrm{NS}$ \\
Ash & 10.06 & 8.00 & 6.40 & 6.09 & 7.02 & $\pm 4.11 \mathrm{NS}$ \\
Ether extract & 5.07 & 4.78 & 5.54 & 4.92 & 4.98 & $\pm 0.49 \mathrm{NS}$ \\
Crude fibre & 8.01 & 8.06 & 8.70 & 9.06 & 8.53 & $\pm 0.71 \mathrm{NS}$ \\
Nitrogen Free & 51.46 & 53.06 & 53.67 & 53.86 & 53.59 & $\pm 2.23 \mathrm{NS}$ \\
Extract & & & & & &
\end{tabular}

Key: $\mathrm{A}=$ Control diet (with no cooked sweet potato tuber), $\mathrm{B}=$ Diet with $\mathbf{2 5} \%$ of maize replaced by peeled cooked sundried sweet potato meal, $C=$ Diet with $50 \%$ of maize replaced by peeled cooked sundried sweet potato meal, D = Diet with $75 \%$ of maize replaced by peeled cooked sundried sweet potato meal, $\mathrm{E}=$ Diet with $100 \%$ of maize replaced by peeled cooked sundried sweet potato meal, $\mathrm{SEM}$ - Standard error of mean, N.S - not significant $\left(\mathrm{P}^{*} \mathbf{0 . 0 5}\right)$.

replicate was weighed weekly to record mean egg weight.

\section{Parameters measured}

The initial weight of birds at point-of-lay and the final weight of the birds at the end of the experiment were taken.

\section{Bodyweight change}

This was done by measuring the difference between the final weight and the initial weight of the quail birds multiplied by 100 .

\section{Feed intake}

The birds were offered weighed amount of feed daily and the corresponding left over weighed and recorded. The difference between the amount fed and the corresponding leftover divided by the 
specified period was the daily feed intake.

\section{Protein efficiency ratio (PER)}

This was determined as a ratio of weight of egg produced to the protein consumed.

PER = weight of eggs $(\mathrm{g})$

Protein consumed (g)

\section{Energy efficiency ratio (EER)}

This was determined as ratio of weight of eggs produced to the energy consumed.

EER $=$ Weight of eggs $(\mathrm{g})$

Energy consumed (kcal/g)

\section{Water consumption}

Daily water consumption was determined accounting for evaporative loss using the procedure outlined by Shoremi et al. (2001).

Mortality records: This was kept throughout the experimental period.

Production parameters measured

\section{Hen day egg production}

This was measured as the total number of eggs laid divided by the number of hens in the house multiplied by 100 . This is given as;

$\mathrm{HDEP}=$ number of eggs produced $\quad \mathrm{x} 100$ number of live birds.

\section{Hen housed egg production}

This was measured as the total number of eggs laid divided by the number of hens originally housed (dead, culled etc inclusive) multiplied by 100 . HHEP = number of eggs produced $\times 100$

number of birds originally housed

\section{Feed conversion ratio}

This was measured as the gram feed consumed per gram of dozen eggs produced.

Egg weight was measured as the average weight of individual egg.

\section{Estimation of economics of production}

The following parameters were used to estimate economics of production:

Cost of feed per kilogram (N/kg) - This was computed using the prevailing market price of ingredients and it's indicated in the formula (Table 1).

Cost of feed per unit weight gain- This was computed as the feed conversion ratio multiplied by the unit price of feed.

Cost of production/bird: The cost of production was estimated as sum of cost of birds, feed, medications, kerosene, charcoal, wood shaving, electric bulbs, measuring cylinder, labour and housing divided by the number of birds in a treatment. Revenue: The revenue was calculated as price per mature bird plus eggs plus the manure harvested in that treatment.

Gross margin/bird: This was calculated as the total revenue generated minus the total cost of production.

\section{Statistical analysis}

Data obtained were subjected to one way analysis of variance (ANOVA) and where significant differences were observed, means were separated using Duncan's Multiple Range Test (Duncan, 1955) as described by Steel and Torrie (1980).

\section{Results and discussion}

Results on performance characteristics of laying quails are presented in Table 3 . The final body weight decreased from $197.75 \mathrm{~g} / \mathrm{bird}$ for birds on the control diet to $194.43 \mathrm{~g} / \mathrm{bird}$ on the sweet potato diets. However, the differences were not significant. Values of $187.38-197.75 \mathrm{~g} / \mathrm{bird}$ obtained in this study were higher than the final body weight of $163-184.33 \mathrm{~g} / \mathrm{bird}$ reported by Edache et al. (2012), 187.55$192.67 \mathrm{~g} /$ bird reported by Akinfenwa et al. (2011) and (180-186.50g/bird) reported by Akpa et al. (2008) and 141.30 - 
$154.00 \mathrm{~g} / \mathrm{bird}$ reported by Odunsi et al. (2007). Body weight change was not significantly affected by the diets. In the report of Ladokun et al. (2007) body weight changes was significantly higher in birds on the complete replacement with sweet potato than on other diets. The lack of significant effect of the diets on body weight change in the present report is in consonance with the report of Akinfenwa et al. (2011) for laying quail.

The feed intake ranged from $28.88 \mathrm{~g} / \mathrm{bird} /$ day (diet A) to $29.98 \mathrm{~g} / \mathrm{bird} /$ day (diet D) but was not significantly affected by the diets. This contradicts the report of Ladokun et al. (2007). In their report, feed intake decreased significantly as the levels of sweet potato increased. The report of Panigrahi et al.(1996) and Aina and Fanimo (1997), on the other hand, supports the present findings. They reported no significant differences between feed intake of chickens on maize -based diets and those on sweet potato diets. Shanaway (1994) had reported that at ambient temperatures of 20 , 28 and $35^{\circ} \mathrm{C}$, feed intake of laying Japanese quail was $20.8,21.20$ and $20.90 \mathrm{~g} / \mathrm{bird} / \mathrm{day}$ but this was not observed in the present study. Values reported in his work Shanaway (1994) seem lower than reported in the present study. As can be observed from Table 1, the energy level of the diets decreased as the level of sweet potato increased. Since birds eat to satisfy the energy requirement (NRC, 1994), the increased effort at feed intake by birds on the various sweet potato meal diets must have led to the similarity in feed intake between the test diets and the control. Previous report by Vasco de Basilio et al. (1997) showed that feed intake was not affected as maize was replaced by sweet potato meal for laying Japanese quails up to $100 \%$ of the diet. Hen-day egg production decreased from 78.11 (diet A) to $73.09 \%$ (diet E) but did not differ significantly between the diets. The values reported in this study are higher than those (77.02 $62.71 \%$ ) reported for laying Japanese quail fed toasted mucuna seed meal (Tuleun and Dashe, 2010) and higher than 66.80$59.40 \%$ reported by Aggoor et al. (2006) for laying quail fed rice bran or broken rice at two different energy levels and higher than that $(75.78-68.60 \%)$ reported by Akinfenwa et al.(2011) for laying Coturnix quail and higher than the $59.00-49.80 \%$ reported by Odunsi et al. (2007) for laying Japanese quail. Aina and Fanimo (1997) reported that egg production did not differ significantly between birds fed maize and sweet potato diets and attributed it to adequacy of dietary protein and metabolizable energy of the diet. This is in agreement withthe result of this work.

Hen-housed egg production reported in this study increased from $69.02 \%$ (diet A) to $73.44 \%$ for birds on diet $\mathrm{C}$ but the differences were not significant which agrees with the report of Tuleun and Dashe (2010) and Kaya and Yildirim (2011) who fed laying chickens with sweet potato vines and may still be due to the adequacy of dietary protein and metabolizable energy. Water intake of birds on the test diets was significantly higher than those on the control $(42.60 \mathrm{~mL} / \mathrm{bird})$. Significant differences also exist between water intake of birds on diets $\mathrm{C}$ and $\mathrm{D}(51.93 \mathrm{~mL} / \mathrm{bird})$ only. Ezieshi et al. (2003) reported that water intake for chicken increased as egg production increased to peak production which is similar to what was observed in the present study. They reported that average water intake per bird was about $300 \mathrm{ml} /$ day in the tropics which was much higher than earlier report (Savory,1978) for laying birds in temperate countries. Water to feed ratio for chicken was about 2.5 buta lack of published data from tropical zones could 


\section{Japanese quails fed diets containing peeled and cooked sweet potato meal}

not allow for comparison (Ezieshi et al., 2003). According to Rajput (2006), daily feed and water consumption for young quail was observed to be $16.25 \mathrm{~g} / \mathrm{bird}$ and $33.07 \mathrm{ml} /$ bird respectively as compared to $29.98 \mathrm{~g} /$ bird and $51.93 \mathrm{ml} /$ bird in the present study. This may be due to differences in climate where the studies were carried out since birds under higher environmental temperatures must consume more water to maintain body temperature. Birds have been reported to consume more water in the tropics in order to control their body temperature (Ezieshi et al.2003).

Feed per dozen eggs increased linearly from control $(0.45 \mathrm{~kg}$; diet A) to $0.49 \mathrm{~kg}$ (diet D) but did not differ significantly. This is similar to the report of Aina and Fanimo (1997) for laying chickens. They reported that there were no significant differences either in feed per dozen eggs or feed per kilogram egg between maize -based diets and sweet potato diets. Similar results have been reported by Ladokun et al. (2007) for laying birds and Vasco de Basilio et al. (1997) for laying Japanese quails fed sweet potato meal diets and by Kaya and Yildirim (2011) for laying chickens fed sweet potato vines. However, this report is contrary to that reported for Japanese quail (Aggoor et $a l ., 2006)$ and may be due to differences in diets utilized.

Feed cost per dozen eggs ranged from N28.89 (diet A) to 30.15 (diet D) with increasing content of sweet potato but the differences were not significant. The valuesfor feed cost per dozen eggs obtained in this study is similar to the cost of feed/egg (2.62-2.23) reported by Tuleun and Dashe (2010). The result of feed cost per dozen eggs in this study followed similar trend with feed conversion ratio. This is in agreement with the feed intake values in the present work.

Table 3: Effects of replacing maize with peeled and cooked sweet potato meal diets on egg laying performance of Japanese quails

\begin{tabular}{lllllll} 
Parameters & $\mathrm{A}$ & $\mathrm{B}$ & $\mathrm{C}$ & $\mathrm{D}$ & $\mathrm{E}$ & SEM \\
\hline Initial weight (g/b) & 155.00 & 155.67 & 155.33 & 155.00 & 155.00 & $0.85 \mathrm{NS}$ \\
Final weight (g/b) & 197.75 & 187.38 & 192.85 & 194.43 & 187.48 & $6.32 \mathrm{NS}$ \\
Weight change (\%) & 27.57 & 20.39 & 24.15 & 25.44 & 20.96 & $3.94 \mathrm{NS}$ \\
Feed intake (g/b/d) & 28.88 & 29.39 & 29.22 & 29.98 & 29.11 & $1.23 \mathrm{NS}$ \\
Water intake (ml/bird/day) & 42.60 & 48.32 & 46.68 & 51.93 & 49.19 & $1.81 *$ \\
Hen-day egg prodn (\%) & 78.73 & 76.68 & 73.83 & 74.83 & 73.09 & $3.75 \mathrm{NS}$ \\
Hen-housed egg prodn (\%) & 69.02 & 66.73 & 73.44 & 73.00 & 72.12 & $5.48 \mathrm{NS}$ \\
Feed/doz. Eggs & 0.45 & 0.47 & 0.48 & 0.49 & 0.48 & $0.03 \mathrm{NS}$ \\
Feed cost/doz. Eggs (N) & 28.89 & 29.90 & 30.09 & 30.15 & 29.50 & $1.88 \mathrm{NS}$ \\
Energy intake & 74.49 & 73.97 & 72.19 & 72.24 & 69.20 & $3.09 \mathrm{NS}$ \\
(kcal/kg/bird) & & & & & & $0.26 \mathrm{NS}$ \\
Protein intake (g/b/d) & 5.78 & 5.88 & 5.85 & 6.00 & 5.79 & $0.007 \mathrm{NS}$ \\
Energy efficiency ratio & 0.15 & 0.15 & 0.16 & 0.15 & 0.16 & $0.099 \mathrm{NS}$ \\
Protein efficiency ratio & 2.03 & 1.86 & 1.89 & 1.86 & 1.87 & 0.54 \\
Mortality (\%) & 2.20 & 2.49 & 0.28 & 0.55 & 0.54 & $1.40 \mathrm{NS}$ \\
\hline
\end{tabular}

a, b, means with same superscripts letters within rows are not significantly ( ${ }^{*} \mathbf{0 . 0 5}$ ) different. SEM, standard error of mea. N.S $=$ not significant, A, control (no sweet potato tuber meal); B, diet with $10.06 \%$ peeled cooked sweet potato meal; C, det with $20.11 \%$ peeled cooked sweet potato meal; D, diet with $30.22 \%$ peeled cooked sweet potato meal; E, diet with $40.23 \%$ peeled cooked sweet potat meal.

Energy intake of laying quail decreased from $74.49(\operatorname{diet} A)$ to $69.20 \mathrm{kcal} / \mathrm{kg}(\operatorname{diet} \mathrm{E})$ but the differences were not significant. This observation was contrary to the report of Aina and Fanimo (1997) for laying chickens fed sweet potato meal for they observed a significant reduction in energy intake between birds fed the maize diet and 


\section{Edache, Tuleun, Oluremi and Carew}

those fed sweet potato diets. The Japanese quail has been reported to be able to adjust feed intake within a wide range of dietary energy levels of between 1700 and $2400 \mathrm{kcal} / \mathrm{kg}$ (Weber and Reid, 1967). This is perhaps responsible for the similarity in energy intake in this study.

Daily protein intake of birds in the present study increased from $5.78 \mathrm{~g} / \mathrm{bird}(\operatorname{diet} \mathrm{A})$ to $6.00 \mathrm{~g} / \mathrm{bird}$ (diet D). However, the differences were not significant. This is in consonance with earlier report (Aina and Fanimo, 1997) for laying chicken.

Economics of production of laying quails fed peeled and cooked sweet potato meal diets (Table 4) showed that birds on the control diet consumed less feed $(28.88 \mathrm{~g} / \mathrm{bird} /$ day $)$ and had the lowest total feed intake $(4.85 \mathrm{~kg} / \mathrm{bird})$ compared to those on the sweet potato diets. This is contrary to report by Ladokun et al. (2007). They reported that feed intake, total feed intake and price of eggs produced were higher on the control than on sweet potato diets. Moreover, final body weight of birds in their work was higher on the control than on the sweet potato diet, which agreed with the report of the present study. In this study, birds on diet $C(66,840.00)$ were superior in revenue and gross margin compared to the control and other test diets. However, gross margin on diets $\mathrm{D}$ and $\mathrm{E}$ are similar to diet C. Similar results have been reported by Ladokun et al. (2007) for laying chicken on sweet potato meal diets. There is a cost saving of $4.21 \%$ on the diet with complete replacement with sweet potato as compared to the maize-based diets.

Table 4: Economics of production of laying Japanese quails fed peeled and cooked sweet potato meal diets

\begin{tabular}{lllllll}
\hline Parameters & A & B & C & D & E & SEM \\
\hline Feed intake(g/bird/day) & 28.88 & 29.39 & 29.22 & 29.98 & 29.11 & $\pm 1.23 \mathrm{NS}$ \\
Price/tray of egg (A) & 300 & 300 & 300 & 300 & 300 & \\
Total feed intake (kg/bird) & 4.85 & 4.94 & 4.91 & 5.04 & 4.89 & $\pm 0.13 \mathrm{NS}$ \\
Feed cost/doz. eggs (N) & 28.89 & 29.90 & 30.09 & 30.15 & 29.50 & $\pm 0.03 \mathrm{NS}$ \\
Final body weight (g/bird) & 197.75 & 187.38 & 192.85 & 194.43 & 187.48 & $\pm 6.32 \mathrm{NS}$ \\
Total price of egg produced (A) & $75980^{\mathrm{a}}$ & $72690^{\mathrm{a}}$ & $81100^{\mathrm{b}}$ & $79920^{\mathrm{a}}$ & $78970^{\mathrm{a}}$ & $\pm 187.98^{*}$ \\
Total no. eggs produced & 7598 & 7269 & 8110 & 7992 & 7897 & $\pm 594.45 \mathrm{NS}$ \\
Total cost of production (N) & $29,521.45$ & $29,629.08$ & $29,622.36$ & $29,874.25$ & $29,202.48$ & $\pm 425.28 \mathrm{NS}$ \\
Revenure (birds/eggs/manure) & $91,480.00^{\mathrm{a}}$ & $88,190.00^{\mathrm{a}}$ & $96,850.00^{\mathrm{b}}$ & $95,670.00^{\mathrm{a}}$ & $94,720.00^{\mathrm{a}}$ & $\pm 194.92^{*}$ \\
Gross margin () & $61,920.00^{\mathrm{a}}$ & $57,027.00^{\mathrm{b}}$ & $66,840.00^{\mathrm{c}}$ & $65,495.00^{\mathrm{c}}$ & $65,559.00^{\mathrm{c}}$ & $\pm 1110^{*}$ \\
\hline
\end{tabular}

Key: a, b, means with same superscripts letters within rows are not significantly ( $\left.p^{*} 0.05\right)$ different. SEM, standard error of mean. N.S =

not significant, A, control (no sweet potato meal); B, diet with $10.06 \%$ peeled cooked sweet potato meal;C, diet with $20.11 \%$ peeled cooked sweet potato meal; $\mathrm{D}$, diet with $30.22 \%$ peeled cooked sweet potato meal; $\mathrm{E}$, diet with $40.23 \%$ peeled cooked sweet potato meal.

\section{Conclusion}

The optimal inclusion level of peeled and cooked sweet potato root meal as a replacement for maize for laying Japanese quail showed a comparable performance in most measured parameters; (feed intake, water intake, hen-day egg production, henhoused egg production, feed/dozen eggs, feed cost/dozen eggs, protein intake, protein efficiency ratio, energy intake, energy efficiency ratio,) with the control. Gross margin for raising Japanese quail on these diets was higher on the 50,75 and $100 \%$ of maize replaced by sweet potato diets than on the control. From the results of this study, peeled and cooked sweet potato meal may completely replace maize in growing and laying Japanese quail diets because there were no adverse effects on performance at this level.

\section{References}

Afolayan, S. B., Dafwang, I. I., Tegbe, T. S. B. and Sekoni, A. 2012. Response of broiler chickens fed on maize-based diets substituted with graded levels of sweet potato meal. Asian Journal of Poultry 


\section{Japanese quails fed diets containing peeled and cooked sweet potato meal}

science, 6: 15-22.

Aggoor, F. A. M., Attia, Y. A., Ismail, F. S. A., Qota, E. M. A. and Shakmak, E. A. 2006. Effect of level and source of dietary energy and/or enzyme additions on productive performance and egg quality of Japanese quail hens.Proc. EPC 2006 XII European Poultry Conference, Verona, Italy 10-14, September, 2006.

Aina, A. B. J. and Fanimo, A. O. 1997. Substitution of maize with cassava and sweet potato meal as the energy source in the rations of layer birds. Pertanika J. Trop.Agric. Sci. 20 (2/3): 163-167

Akinfenwa, F. A., Bawa, G. S. and Sekoni, A. A. 2011. Laying performance of Japanese quail fed varying levels of dietary lysine. In: A.A. Adeniji, E.A. Olatunji and E.S. Gana (eds). Proc. $36^{\text {th }}$ Ann. Conf. Nig. Soc. Anim. Prod. Merit House, Raw Material Research and Development Council, Abuja, 1316 March, pp380-383

Akpa, M. O., Alaku, S. O. and Atseomajumi, E. D. 2008. Effects of varying levels of crude protein on short term egg production of Japanese quail (Coturnixcoturnix japonica) in a humid tropical environment. In: Bawa, G.S., Akpa, G.N., Jokthan, G.E., Kabir, M. and Abdu, S.B. (eds). Proceeding of $13^{\text {th }}$ Annual conference Animal science Association of Nigeria,Ahmadu Bello Bello University, Zaria, Sept. 15-19 pp 410-412.

AOAC 2000. Official methods of analysis, Association of Official Analytical Chemist Inc. $15^{\mathrm{TH}}$ Ed. Washington.

Duncans, D. B. 1955. Multiple range and multiple F - test. Biometrics, 11: 1 42
Edache, J. A., Njike, M. C. and Ehiobu, N. G. 2003. Influence of dietary proteins on quality and hatchability of Japanese quail (Coturnix coturnix japonica) eggs. Journal of Agriculture Science \& Technology 13 (2) 110-116

Edache, J. A., Yisa, A. G. and Okpala, E. J. 2012. Effects of replacing maize with yam peel on short term laying performance of Japanese quails (Coturnix coturnix japonica). Pakistani Journal of Nutrition 11(7): 614-617

Ezieshi, V. E., Nworu, M. J., Bandele, F. O., Suleman, R. O., Ojurongbe, B. C. and Olomu, J. M. 2003. Laying hen productivity in the tropics as affected by stage of egg production, feed restriction, stocking density and time of day. Archives de Zootenica vol. 52, no. 200: 475-482

Kaya, S. and Yildirim, H. 2011. The effect of dried sweet potato (Ipomea batatas) vines on egg yolk colour and some egg yield parameters. Int. J. Agric. Biol., 15: 766-770

Ladokun, O. A., Aderemi, F. A. and Tewe, O. 0. 2007. Sweet potato as a feed resource for layer production in Nigeria.African Crop Science Conference Proceedings vol. 8 pp 585-588

Maphosa, T., Gunduza, K. T., Kusina, J. and Mutungamiri, A. 2003. Evaluation of sweet potato tuber (Ipomea batatas) as a feed ingredient in broiler chicken diets. Livestock Research for Rural Development 15(1).

Martins, B. 1987. Guinness World birds, Guinness superlatives Ltd, pp. 158

Musa, U., Haruna, E. S. and Lombin, L. H. 2008. Incubation and Hatching of quail eggs.Quail production in the tropics, ISBN - 978-166-717 
-6. PUB. NVRI, Vom, printed by NVRI press; pp 24-37

Neild, R. C. 1992. Extension horticulture culturists.Published by cooperative extension Institute of Agriculture and Natural Resources.University of Nebraska, Lincoln.Maitu: pub@unl.edu? Subject-comments from G75

NRC 1994. Nutrients Requirements of Domestic Animals. In: Nutrient Requirement of Poultry. $9^{\text {th }} E d n$., National Academy of Science, Washington, D.C., USA., pp 7173.

Oboh, S. O. 1987. Biochemical composition and utilization of sweet potato (Ipomeabatatas)in broiler rations. Ph.D Thesis, University of Ibadan, Ibadan, Nigeria.

Odunsi, A. A., Rotimi, A. A. and Amao, E. A. 2007. Effect of different vegetable protein sources on growth and laying performance of Japanese quails (Coturnixcoturnix japonica) in a derived savannah zone of Nigeria.World Applied Sciences Journal 3 (5): 567-571

Panigrahi, S., Oguntona, E. B. and Roberts, B. R. 1996. Effects of oven drying tubers of two high protein sweet potato varieties at different temperatures on their feeding value in broilers.British poultry science, 37: 173-188

Purseglove, J. W. 1991. Dicotyledons; Tropical crops.Longman Scientific and Technical. John Wiley and Sons, Inc. NY, USA

Rajput, M. S. 2006. Frequency of feed and water intake by quail and it's relationship with behavior and production .SAUT, Tandojam (Pakistan) 71p

Robbins, G. E. S. 1981. Quail, their breeding and management.
Publisher-World Pheasant Association (WPA) 1, 9, 10.

Steel, R. G. D and Torrie, J. A. 1980. Principle and procedure of Statistics.A biometrical approach. $2^{\text {nd }}$ ed. McGraw Hill Book Co. New York, USA.

Shanaway, M. M. 1994. Quail production systems, a review. Published by F.A.O., Rom, Italy.

Savory, C. J. 1978. Water utilization of laying chickens.Brit. Poult. Sci. 19: 631-641

Shoremi, O. I. A., Akor, H. A., Igoche, L. E. and Onaa, S. O. 2001. Supplementations of sweet potato (Ipomeabatatas) forage in weaner rabbitsconcentrate mash. Discovery and Innovation $15(1 / 2): 55-58$.

Tewe, O. O. 1992. Biochemistry and utilization of sweet potato (Ipomea batatas) for livestock feeding: Implications for food security in Africa. In: Akoroda, M.O. (Ed). Int. Soc. Tropical Root CropsAfrica Branch.ISTRC-AB, CTA, IITA. 452P

Tuleun, C. D. and Dashe, N. A. 2010. Effects of dietary levels of toasted mucuna seed meal on the performance and egg quality parameters of laying Japanese Quails (Coturnixcoturnix japonica). International Journal of Poultry Science 9 (12): 1092-1096.

Vasco de, B., Real, F. and Romero, $M$. 1997. Archivos Latino americanos de Produccion Animal, vol. 5, no. 3

Weber, C. W. and Reid, B. L. 1967. Protein requirements of Coturnix quail chicks at 5 weeks of age. Poultry Science, 46: 1190-1194

Received: $15^{\text {th }}$ November, 2017

Accepted: $20^{\text {th }}$ February, 2018 